\title{
Toward a Rural Philosophy of Education
}

\author{
V. Sue Atkinson ${ }^{1}$ \\ Binghamton University
}

Over the years of my school life as a student and as an educator, I have seen education become more standardized and less community based. Going further back in time than my personal history, much has changed since the days of common schools that carried out the curriculum of the community and reflected its language, religion, and culture. The $20^{\text {th }}$ century saw increased standardization of schools and the embracing of a managerial "one best system" (Tyack, 1974) in which schools reflected and contributed to a rapidly standardizing and urbanizing society. Mass production, automation, and standard clothing sizes (DePoy \& Gilson, 2009, p. 32) were followed by standardized tests that sorted and placed students into specialized tracks to prepare them for their future roles in society (Kliebard, 2004).

The 21 st century has only accentuated that trend-more testing, emphasis on education as a free market (Apple, 2006), and a shrinking role for community. Neoliberalism provides a veneer of egalitarianism for greed and the exploitation of natural resources and people (Berry, 1990), and place matters little when one exurban housing development or strip mall looks much like any other. The Common Core curriculum and its successors, national standards and testing, and entrepreneurial educational enterprises both support and benefit from this standardization. In contrast to the sense of place (Fitchen, 1991; Morgan et al., 2009) that anchors rural perspectives, in this system, it doesn't matter where you are; education is supposed to be the same.

\footnotetext{
${ }^{1} \mathrm{~V}$. Sue Atkinson, corresponding author, atkinson@binghamton.edu
} 
Rural philosopher Wendell Berry (1978) warned that "The first casualties of the exploitive revolution are character and community" (p. 9). In this essay, I use the work of Wendell Berry, as well as that of educational historian Paul Theobald and other rural education scholars and researchers to outline considerations related to developing a rural philosophy of education. I consider policy issues, history, and current economic, political, and cultural challenges, outlining some differences, strengths, and needs of rural education that must be addressed in the formation of such a philosophy.

\section{Rural communities, rural schools- no respect, or worse, invisible}

Every institution, policy, and practice —especially those that now dominate education and larger society — establish relations of power in which some voices are heard and some are not. Although it is not preordained that those voices that will be heard most clearly are also those who have the most economic, cultural, and social capital, it is most likely that this will be the case. (Apple, 2006, p. 229) Many education writers and researchers appear unaware of the unique characteristics and needs of rural schools and the communities that support and are supported by them, even though over nine million students attend a school classified as "rural" by the National Center for Education Statistics (2007). These students constitute $20 \%$ of schoolchildren in the United States, and an additional six million students attend schools in small towns that many would consider rural (Strange, 2011), despite recent and continuing population shifts away from rural areas, and the decline of traditional rural employment in fields such as agriculture.

Small rural schools have many strengths, but many challenges as well, not the least of which is the poor image, or even invisibility, of rural areas and the people who live there. Public officials and others greet rural issues with neglect, sometimes combined with outright scorn, or 
view rural life as (ironically) unsustainable. In a well-publicized Playboy interview in 1982, former New York City mayor Ed Koch referred to rural life as "a joke," describing it as, "When you have to drive 20 miles in a pick-up truck to buy a gingham dress or a Sears, Roebuck suit" (Soffer, 2010, p. 231). While our vocabulary contains few derogatory words for urban residents as a whole, there are many for rural residents—-crackers, rubes, hayseeds, hicks, hillbillies, bumpkins, peasants, rednecks, yokels, and white trash” (Bassett, 2003, p. 3; Strange, 2011). Academia overall has not embraced rural issues; in the vast majority of academic writing, poverty is an American urban issue or an issue in developing countries. Finally, public opinion of rural dwellers, while admiring their "old fashioned values," also subsumes stereotypes of people who are unsophisticated, "behind the times," "hicks," or "rednecks"2" (W. J. Kellogg Foundation, 2001, pp. 8-9). Comedians find it socially acceptable to ridicule rural residents, as the cultural capital of rural dwellers is systematically devalued.

The root word of "respect" means "to look at (hooks, 1994, p. 186). Worse than being looked down upon is not being seen at all. As I searched library holdings, I found that my searches for information on rural poverty and rural development netted almost entirely sources on developing countries. This was puzzling, given my university's location in rural upstate New York, and the existence of rural poverty not far from campus. I also noted that this University offered few sociology, social work, or education courses that focus on rural issues. "While there is a veritable academic industry devoted to chronicling urban decline, small towns' struggles are off the grid" (Carr \& Kefalas, 2009b).

Rural voices were missing throughout my university. Students and faculty strived to do work that reflected an awareness of issues of race, class, and gender, and sensitivity to urban

\footnotetext{
${ }^{2}$ In the early 1900s, working class rural residents proudly termed themselves "rednecks," people who did real work, as opposed to "pale and wan elitist and affluent upper classes" (Apple, 2006, p. 133).
} 
poverty, but rural matters were often viewed as of historical, but not current, interest. I wondered what other part of society I could possibly have come from that would net that response. I have lost count of the number of times that as a graduate student in education I was assigned readings or participated in discussions about urban or suburban schools, while the needs of rural schools remained part of the null curriculum. Adrienne Rich (1986) described the "moment of quiet disequilibrium, as if you looked in the mirror and saw nothing," her response to a teacher who "describes the world and you are not in it" (p. 200).

Much attention is focused on the problems and needs of urban schools. A common image of struggling schools and neglected students was described by Jonathan Kozol (2005) in Shame of the Nation: decaying school buildings in a central city attended by students of color who lived in dangerous, drug-infested neighborhoods in female-headed, single-parent households dependent on public assistance. However, a significant number of schools attended by children who live in poverty do not fit this description. Poverty in rural areas and rural school districts is prevalent and persistent. A higher percentage of rural families are poor (15\%) compared to urban families (12.5\%). This has been true every year since 1960, as most geographic areas of highly persistent poverty are rural (Annie E. Casey Foundation, 2008; Jensen, 2006), and 48 of the 50 counties with the highest poverty rate are rural. These numbers rise with each recession, and Census Bureau figures show $29 \%$ of young children in rural areas living in poverty (Mattingly \& Stransky, 2010).

Rural poverty suffers from a low profile in the media. When "welfare reform" was implemented in the 1990s, a study of 1400 newspaper articles on the topic found that none mentioned rural welfare recipients (O’Hare \& Johnson, 2004). Rural schools also go largely unnoticed. In 2001, of 264 "Blue Ribbon Schools" (a US Department of Education program that 
recognizes schools based on academic performance), $46 \%$ of which were low-income, only $5 \%$ were rural (Bassett, 2003).

\section{Rural History: Keeping them down, on the farm}

Rural residents have faced challenges throughout our country's history. While history books tell of brave settlers on the frontier, supported by government land grants, there is another story--of continued attempts by powerful business interests to contain those settlers and keep them as an underclass. From Shay's Rebellion in 1786, when the armed forces of our new nation were used to protect mortgage holders' rights to foreclose on the farms of unpaid Revolutionary War veterans, to the upstate New York Anti-Rent Wars in the $19^{\text {th }}$ century, in which Catskill area farmers protested the feudal system of excessive land rents that dated from the days of the Dutch patroons, to crop liens in the western territories and a monetary policy that kept settlers literally “dirt poor" (Theobald, 1997), government policies favored business interests over those of rural residents.

Near the end of the $19^{\text {th }}$ century, the populist movement, which had strong roots in rural areas (Apple, 2006), was "the last forthright attempt by rural dwellers to put the country on an equitable course, on a trajectory that would attend to the interests of the producers as well as those of the commercial interests" (Theobald, 1997, p. 97). Losing the battle over monetary policy, the movement dwindled, the Democratic party turned to corporate liberalism, and farmers lost out.

In the early $20^{\text {th }}$ century, migration from farm to city became a widespread concern. "The city sits like a parasite, running out its roots into the open country and draining its subsistence," wrote Liberty Hyde Bailey (Theobald, 1997, p. 103). His Cornell University-based Country Life Movement aimed to educate students about their rural heritage, connecting their schooling to 
their farm life, nature, and environmental studies (Kliebard, 2004), preaching the virtues of country over city life, in an effort to keep the "best and brightest" (Theobald, 1997, p. 105) on the farm. Along with proposals for free mail service, agricultural extension programs, and road improvement, Bailey recommended that rural schools adopt Dewey's more democratic, experience based, and hands-on type of education and apply these methods to nature study, rather than rely on recitation methods more common at that time (Theobald, 1992). This valiant effort to maintain a rural middle class floundered, partially over Bailey's locally unpopular recommendations for consolidation of small rural schools into large central facilities.

By 1920, efforts to keep young people "down on the farm" had been abandoned, and the percentage of adults earning a living from farming shrank from $40 \%$ to less than $2 \%$ in 2000 (Wood, 2008). Farm policies consistently supported big farming and agri-business over family farms, with huge land grants to the railroads, railroad pricing structures that favored grainelevator operators over local distribution of crops, and more recently, federal farm policies that cause alternating surpluses and shortages. Artificially low commodity prices drove farmers out, or forced larger and larger operations, with huge debt burdens that then disadvantaged farmers when monetary policy favored creditors.

Similar to the decline experienced in urban areas, rural areas continued to decline as suburban growth was subsidized politically and economically in the 1950s, for example, by the 1956 National Defense Highway System. Now, after more than 100 years of supporting corporations over farmers, neoliberals "sell despotism and avarice as freedom and democracy" (Berry, 1978, p. 11), advocating choice and free-market principles (with some notable exceptions in the form of agricultural policy) that keep agricultural prices low, cause an exodus of business 
and jobs, and leave rural families with choices that have resulted in a brain drain and a youth drain on rural areas.

\section{Class replication, or something else?}

The work of many theorists shows urban bias and is based on urban models. Marx and Engels (1848/1988) dismissed rural folks with their infamous remark about "the idiocy of rural life" ${ }^{\prime 3}$ (p. 14). Rural lifestyles are not incorporated into theory, and are dismissed as quaint relics of the past or obstacles to progress.

Bowles and Gintis' (1976) work on class replication in schools has been criticized for not giving account to gender, and it failed to explicitly address rural issues as well. Anyon's (1981) work looked at schools serving five different social classes or class fractions, finding that the type of education that children received in these schools was both very different from the others and highly related to the presumed role these children would assume as adults in the workplace and in society. However, most rural schools serve a range of socioeconomic groups - the children of the working/middle class, small business owners, and farmers, who tend to constitute the higher class, as well as the working ${ }^{4}$ and unemployed poor. Clearly, these scholars made legitimate research choices, but where is the work on class that draws on rural populations, or include data generalizable to that population?

It is unclear how the work of Bowles and Gintis, Anyon, and others apply to small rural schools. The class structure of rural communities is not identical to urban and suburban areas. There is a well-known divide of newcomers and old-timers, and deeper, stronger, and less

\footnotetext{
${ }^{3}$ [The bourgeoisie] "has created enormous cities, has greatly increased the urban population as compared with the rural, and has thus rescued a considerable part of the population from the idiocy of rural life" (Marx \& Engels, 1848). [italics added by author]

${ }^{4}$ (Rural poor people are more likely to be employed than are the urban poor (Huang \& Howley, 1991; O'Hare \& Johnson, 2004).
} 
recognized schism between the small town working and middle class and the rural poor. Class replication appears to be accomplished in different, and confounding, ways. The seemingly low aspirations of and for rural youth, evidenced by lower college attendance and completion despite high school achievement (NCES, 2007) are at least partially the result of unique economic and social circumstances.

Out-migration of 20-30 year olds from rural areas is a persistent trend, and young people from rural areas are more likely than urban dwellers to leave the place where they grew up, and to experience more conflict over that decision (Boethel, 2000). While some young people who leave rural areas in search of educational, employment, and social opportunities return to raise families, most do not (Carr \& Kefalas, 2009a; O’Hare \& Johnson, 2004). Unlike the migration from rural areas that occurred during the 19th century (Ferrie, 2003), it is now the better educated youth who leave rural areas and lifestyles behind (Heminway, 2002; Huang \& Howley, 1991), placing families in the difficult situation of weighing conflicting priorities of wanting their children to follow in their footsteps and wanting the best for their children. Like all parents, rural dwellers want their children to do well, but this comes with the risk of them leaving the area and their lifestyle behind. Rural youth find themselves in a situation similar to the youth of ethnic groups who feel they must deny their culture to get ahead, and hence contribute to its destruction. Rural youth, who report feeling "more empty and angry about their futures" (Howley et al., 1996, p. 151) are presented with a difficult choice: "to leave family and land to find a future, or to stay and suffer from low aspirations and a poor self-image" (Heminway, 2002, p. 10). Rural economic development policies that focus on bringing in low wage and lowskill jobs exacerbate this trend (Arnold, 2004), which contributes to a cycle in which children continue to grow up in communities with fewer highly educated adult role models. 
Carr and Kefalas (2009b) wrote in their study of rural youth out-migration from the Midwest,

In a postindustrial economy that places such a high premium on education and credentials, the flight of so many young people is transforming rural communities throughout the nation into impoverished ghost towns. A new birth simply cannot replace the loss that results every time a college-educated twentysomething on the verge of becoming a worker, taxpayer, homeowner, or parent leaves. And as more manufacturing jobs disappear every day, the rural crisis that was a slow-acting wasting disease over the past two decades has evolved into a metastasized cancer. (p. 3)

Carr and Kefalas (2009a) documented this out-migration, particularly the shift of population to both coasts, and identified four types of students: Approximately $40 \%$ were working-class "stayers"; $20 \%$ they term college bound "achievers" who left home not just for college but often permanently; "seekers" were the $10 \%$ who join the military ${ }^{5}$ as a vehicle to seeing the larger world; and the remaining $30 \%$ were "returners," who left, but eventually returned to their hometowns. Only a small percentage of the returners were professionals.

Adults in the community actually encouraged the best and brightest young people to leave and simultaneously underinvested in those who chose to stay. "The best kids go while the ones with the biggest problems stay, and then we have to deal with their kids in the schools in the next generation," (Carr \& Kefalas, 2009b, p. 6) stated a high school guidance counselor in the study. High achieving students were encouraged to do well in school and cultivated to leave. These were students who liked school and credited their teachers and school experiences for their

\footnotetext{
${ }^{5}$ Rural young people make up a disproportionate share of the military and of deaths in military conflicts and wars (O'Hare, 2007).
} 
success, while the "stayers" viewed school as an alienating experience and entered the labor force early, with little encouragement to seek further education or training. Thus rural children were taught to equate success with leaving home.

\section{Fighting for survival—consolidation threatens rural schools and communities}

The number of children in many rural communities has decreased over the past several decades, in some areas causing a crisis in the schools as enrollment has dropped precipitously. One often-proposed solution to declining enrollment is consolidation, or joining two or more small school districts together. The goal of this business-model solution to the problems of rural schools is the create larger, more efficient schools; consolidation of very small districts is promoted as a cost-effective way to address many problems of poor rural schools (Duncombe \& Yinger, 2005). Consolidation can negatively affect both rural communities and rural students. Communities lose their center, and students lose the advantages of small schools (O'Hare \& Johnson, 2004), again demonstrating that an urban "one best system" (Tyack, 1974) is not best for rural schools (Lockette, 2010; O’Hare \& Johnson, 2004). Small size is an advantage when it means that students interact more frequently with teachers, teachers get to know students better, and students have more opportunities to participate in extra-curricular activities. Parent involvement and partnerships between home and school result in better academic outcomes (Beaulieu et al., 2003), and build social capital in families, school, and community (Allen, 2007). Rural schools, with overall high test scores, graduation rates, and teacher satisfaction, and low rates of behavior problems and absenteeism compared to urban schools (NCES, 2007), ironically are offered financial incentives to disappear.

“College and career ready"? 
I have watched as students from our small communities leave for college, come home for Thanksgiving, and never go back. Students in rural communities need support in order to access post-secondary education successfully. Rural students are more likely to get college information from school personnel than from their parents. Many students and their parents are unfamiliar with the forms, the language and acronyms, and the timeline of college and financial aid searches and applications (Bassett, 2003). Some have never seen a college campus. They need assistance in understanding and interpreting their college acceptance letters and financial aid packages, as many do not have family or friends to help with this. They need follow-up over the summer, a critical time in the transition (Arnold et al., 2009). They also need support once they start college. Many thrive academically, but have trouble fitting in, especially at urban colleges or private colleges that enroll the children of the upper class (Bassett, 2003). Rural communities and schools, or the colleges their graduates attend, need to track and support these students.

Rural young people also need information about careers and opportunities that exist in their local area if they want to stay or return. Rural communities need to help youth who want to stay in the area instead of giving able students the message that success equals getting out of town (Carr \& Kefalas, 2009a). Connecting students with local businesses, for example, reduces youth out-migration (Khattri et al., 1997). Rural youth will come back to rural communities if there is something to come back to. As Dorothy discovered when she left her barren Kansas farm life for the glamour of $\mathrm{Oz}$, there really is "no place like home" for many rural residents. ${ }^{6}$

\footnotetext{
${ }^{6}$ This analogy appears in Wood (2008), Survival of Rural America.
} 


\section{Rural economic development and rural education}

The $16^{\text {th }}$ century French essayist and critic of colonialism Montaigne wrote despairingly about "the richest, the fairest and the best part of the world topsiturvied, ruined and defaced for the traffick of Pearls and Pepper" (Lewis, 2007, p, 172).

Rural economic development often depends on exploitation of people and the environment. Whether the desired resource is water, coal, minerals, natural gas, or land to site a garbage or hazardous waste dump, or a prison, "rural America has become a dumping ground for the waste products of urban core areas. With the decline in extractive industries, the quality of the environment may be one of the last marketable resources available in many rural communities” (Miller, 1993, p. 100). Over the years, New York City has essentially colonized upstate New York through watershed takings, subsequent restrictions on upstate economic development, and the recent threat of further exploitation through proposed high-density drilling for natural gas in areas deemed not worth preserving, calling to mind economist and sociologist Thorstein Veblen's (1979/1899) description of conspicuous consumption of urban society, which depends on limitless production, itself dependent on the exploitation of nature, distant and invisible.

Divergent voices add to the discussion of rural economic development. "New Ruralism" aims to combine principles of sustainable agriculture and new urbanism to create a different type of rural development, and an alternative to typical urban sprawl (Kraus, n.d.), while "Radical Ruralism" criticizes that movement, seeing hegemonic dominance of rural landscapes by new urban residents (Wilbur, 2013). The Radical Ruralism movement seeks to re-invigorate rural regions with a democratic approach to rural development that re-empowers rural areas and people to end their domination by urban interests. 
Free-market capitalism is cited by rural advocates as a cause of rural decline (Wood, 2008). As elsewhere, big-box retailing has diminished local business ownership, and unions and blue-collar wages are in decline. The rise of agribusiness means that there are fewer farmers in America's agricultural regions, and of the $2 \%$ of Americans who operate farms, $42 \%$ of those in the Midwest earn less than \$20,000 per year (Carr \& Kefalas, 2009). Theobald and Nachtigal (1995) questioned modern application of economic theories of individual self-interest creating common good, calling it a legitimating of corporate betrayal of communities that asks us "to believe that an invisible hand somehow lifts a factory out of a community in the United States and places it in Mexico without anyone's bothering to will it to happen" (p. 133).

\section{Restoring community, building cultural and social capital through rural education}

Restoration of community must anchor rural development and school reform efforts, but challenges abound. History records many accounts of communities that approached potential members who were not white, Protestant, or heterosexual in highly oppressive ways. Noddings (2002) wrote about the trade-offs that come with efforts toward community and the challenges faced in a heterogeneous society to balance respect for diversity and the need for community, and to establish community that honors that diversity and yet has shared values. Bellah et al. (1985) contended that community spirit has been sacrificed to individualism, and drew a contrast between true communities and "purposive-rational, loosely linked groups seeking to solve their individual problems" (p. 64). These neoliberal "communities" consist of ever-changing groups of people who come together around a temporary interest for as long as that meets their needs. Noddings also cited concern that liberalism overemphasized the autonomy of individuals and neglected the role of community, citing Weber's description of a society “dominated by a bureaucratic and therapeutic mentality" (Weber et al., 1958/1905, p. 65). 
Neoliberal society seeks procedural fairness, claiming that this ensures an individual's ability to pursue their own legitimate good. However, this has not been working well for rural communities. A vision for rural community might better be that which Noddings (2002) attributed to traditionalists and communitarians: "[It] must stand for something; it must establish and discuss the good it seeks" (p. 65). Rural communities are places where opinions diverge, and authoritarian populism and all types of conservative viewpoints, from neo-conservative to conservative-libertarian-survivalist run strong, but "a community is a place where people who may not like one another nevertheless work together to advance the welfare of that which they hold in common" (Theobald, 1997, p. 121).

While Wendell Berry (1990) questioned the ability of schools to drive social change, he nevertheless prescribed a larger and different role for them (Theobald, 1992). He criticized current rural schools for focusing too much on training students to become producers and consumers, disagreeing with the idea that "the purpose of education has been to prepare people to 'take their place' in an industrial society" (Berry, 1990, p. 25). He advocated democratic, Deweyan teaching methods that incorporate rural knowledge and concerns, and that encourage students to exercise agency to make their lives better and maintain harmony with nature, living "as though [our] grandchildren would also be alive, in this land, carrying on the work we're doing right now, with deepening delight” (Snyder, 2013, p. 48). Such sustainable practices are central to Berry's philosophy of building cultural capital and community that can last.

Rural schools and their students' needs reflect the larger issues of rural communities. In fact, there is comparatively greater impact of the community on achievement in rural schools compared to those in suburban and urban settings (Beaulieu et al., 2003). Theobald (1997) held that schools can have a central role in rebuilding rural communities. Rather than waiting to be 
rescued by economic development programs, schools can be a catalyst. So-called Progressive education-large systems headed by professional administrators who are not educators, emphasis on preparing students for jobs in an ever-changing market that are dependent on mobility and divorced from the place where they are located, and narrow measures of successoffers little to rural communities. Small schools draw on current pedagogical knowledge that recognizes the importance of background knowledge, culture, and connection to students' dayto-day lives (Allen, 2007). There is a need to re-culture, not restructure, rural education to counteract destructive cultural messages that suggest that urban is better than rural and that bigger is better than small (Theobald, 1997), and to resist urban cultural imperialism.

\section{Rural Pedagogy — Community based, democratic, community-oriented}

Place-based development aims to capitalize on unique characteristics of a particular place (Morgan et al., 2009). Applied to education, it is the antithesis of standards-based instruction. Linkages to their community provide schools ways to give students a sense of purpose, help make students effective community members, and bring relevance to the curriculum. Focusing on place-based learning and using the community as a curricular lens contributes to re-creating community and enhances rural pedagogy by making learning more experiential and therefore more powerful, and also by providing students with opportunities to understand who they are and how they might find their place in the world (Theobald \& Nachtigal, 1995).

The curriculum must grow out of real issues important to the students and the people in a particular community. Activities that connect with the students' own experiences, that require the use of skills from various disciplines, that are carried out in cooperation with others, and that result in a useful product give students the most powerful kinds of learning experiences, similar to the educational approach advocated by Dewey (1966/1934). This approach also provides 
students with a deep understanding of the connection between information in a textbook and the lives their families and friends lead. It gives students the opportunity to be a part of society now rather than at some time in the distant future, and involves students in the struggle to solve complex issues that are important to their community, providing not only powerful learning, but also reducing alienation among young people (Slattery, 2006; Theobald \& Nachtigal, 1995). This is, indeed, educating for democracy.

Rural education has many strengths to build on. Although rural teachers earn lower salaries than do their urban or suburban counterparts (Jimerson, 2003; NCES, 2007; Rural School \& Community Trust, 2003), they report greater job satisfaction and fewer problems with discipline (NCES, 2007). Rural schools have a lower student: teacher ratio than urban or suburban schools (NCES, 2007). Small schools and closer relationships with teachers, who may also be community members, allow for more meaningful teacher-student relationships and the development of social capital. Rural teachers must know about and teach students about their rural heritage and rural history. Programs such as Foxfire (Oliver \& Howley, 1992) help students learn about their own culture, providing an education that is richer, not more parochial, for its local emphasis. An added benefit of this approach is that multicultural education, which is badly needed in rural schools, is made more understandable and relevant to students, because these students know and appreciate their own culture as well. Community-based curricula must be a significant part of rural schooling. Even students who seem detached, lazy, and unmotivated, can contribute when given something meaningful to do. Community based instruction is "messier and more complicated" (Boethel, 2000, p. 18) but it is good pedagogy.

Technology must be used strategically and carefully to extend the reach of rural residents in ways that will enrich their lives, diminish isolation, and open up new worlds to rural youth. 
Technology as a teaching tool and as a means of conducting research within the classroom and school can enrich the curricular experiences of rural students. However, technology as a servicedelivery method, with instruction delivered via distance learning methods, contradicts much research on the importance of interpersonal relationships in education, and fails to draw on the unique strengths of rural schools (Beaulieu et al., 2003).

\section{In Conclusion}

Rural education, rather than being education's poor stepchild, needs to take the lead. The approaches above can be solutions to a number of problems facing all schools, and indeed, much of society. Creating sustainable community is a goal for many places. Blighted urban areas need this sustaining vision just as much as rural ones. Wendell Berry speaks to this issue:

My feeling is that if improvement is going to begin anywhere, it will have to begin out in the country and in the country towns. This is not because of any intrinsic virtue that can be ascribed to rural people, but because of their circumstances. Rural people are living, and have lived for a long time, at the site of the trouble. They see all around them, every day, the marks and scars of an exploitive national economy. They have much reason, by now, to know how little real help is to be expected from somewhere else. They still have, moreover, the remnants of local memory and local community. And in rural communities there are still farms and small businesses that can be changed according to the will and desire of individual people. (Berry, 1990, p. 168)

Jefferson, Thoreau, and Emerson wrote about the national importance of a healthy rural society (Theobald, 1992). In order to maintain that healthy rural society and healthy rural schools, a guiding philosophy of rural education is needed. Rural schools and communities are 
not served by an approach that seems to say, there aren't enough jobs, let's get some; there aren't enough students, lets consolidate; technology is good, let's get more (Theobald \& Nachtigal, 1995). A rural philosophy of education needs to clearly articulate the value of community, respect for the natural environment, and sustainability across generations, and refute neoliberalism's attempt to corrupt the concept of the individual. Rural education must include attention to rural history as a guide as well as a source of curriculum, it must respect and teach local rural culture, it must incorporate experiential, community-based teaching and provide postsecondary educational support coupled with measures to stanch youth out-migration, and it must actively resist economic exploitation and support sustainable economic development. Rural communities and rural schools must found their philosophy of education on democracy, cooperation, hard work, and relationships. 


\section{References}

Allen, J. (2007). Creating welcoming schools. Teachers College Press.

Annie E. Casey Foundation. (2004). Strengthening rural families: The high cost of being poor. http://www.aecf.org/upload/publicationfiles/rf2022k560.pdf

Anyon, J. (1981). Social class and school knowledge. Curriculum Inquiry, 11(1), 3-42. https://doi.org/10.1080/03626784.1981.11075236

Apple, M. (2006). Educating the "right” way: Markets, standards, God, and inequality (2 ${ }^{\text {nd }}$ ed.). Routledge.

Arnold, K., Fleming, S., DeAnda, M., Castleman, B., \& Wartman, K.L. (2009). The summer flood: The invisible gap among low-income students. Thought \& Action, 25, 23-34.

Arnold, M. (2004). Guiding rural schools and districts: A research agenda. Midcontinent Research for Education and Learning. https://files.eric.ed.gov/fulltext/ED484397.pdf

Bassett, D. L. (2003). Ruralism. Iowa Law Review, 88, 273. https://doi.org/10.2139/ssrn.443120

Berry, W. (1978). The unsettling of America: Culture and agriculture. Avon.

Berry, W. (1990). What are people for? North Point Press.

Boethel, M. (2000). Thriving together: Connecting rural school improvement and community development. Southwest Educational Development Laboratory. ED 451020. https://files.eric.ed.gov/fulltext/ED451020.pdf

Bowles, S., \& Gintis, H. (1976). Schooling in capitalist America: Educational reform and the contradictions of economic life. Basic Books. 
Beaulieu, L. J., Israel, G. D., \& Wimberley, R. C. (2003). Promoting educational achievement: A partnership of families, schools, and communities. In D. L. Brown \& L. E. Swanson (Eds.). Challenges for rural America in the twenty-first century (pp. 273-289).

Pennsylvania State University Press.

Bellah, R., Madsen, R., Sullivan, W. M., Swidler, A., \& Tipton, S. M. (1985). Habits of the heart: Individualism and commitment in American life. University of California Press.

Carr, P. J., \& Kefalas, M. J. (2009a). Hollowing out the middle: The rural brain drain and what it means for America. Beacon Press.

Carr, P. J. \& Kefalas, M. J. (2009b, September 21). The rural brain drain. Chronicle of Higher Education. http://chronicle.com/article/The-Rural-Brain-Drain/48425/

DePoy, E., \& Gilson, S. F. (2009). Studying disability: Multiple theories and responses. Sage.

Dewey, J. (1966). The need for a philosophy of education. In R. D. Archambault, Ed., Dewey on education. (pp. 3-19). Random House. (Original work published 1934).

Duncombe, W. \& Yinger, J. (2005). Does school district consolidation cut costs? Center for Human Policy, Syracuse University. https://www.maxwell.syr.edu/uploadedFiles/cpr/research/cpr_research_education_financ e_policy/Does_School_Consolidation_Nov_05.pdf

Ferrie, J. P. (2003). How ya gonna keep 'em down on the farm when they've seen Schenectady?: Rural to urban migration in the U.S., 1850-60. Working Paper. http://faculty.wcas.northwestern.edu/ fe2r/papers/urban.pdf

Fitchen, J. M. (1991). Endangered spaces, enduring places: Change, identity, and survival in rural America. Westview Press. 
Heminway, M. T. (2002, May). Maine's disappearing youth: Implications of a declining youth population. Maine Leadership Consortium, Augusta, ME.

hooks, b. (1994). Teaching to transgress: Education as the practice of freedom. Routledge. https://doi.org/10.3366/para.1994.17.3.270

Howley, C.B., Harmon, H.L., \&. Leopold, G.D. (1996). Rural scholars or bright rednecks? Aspirations for a sense of place among rural youth in Appalachia. Journal of Research in Rural Education, 12(3), 150-160.

Huang, G. \& Howley, C. (1991). Recent trends in rural poverty: A summary for educators. ED 335 180. https://www.ericdigests.org/pre-9221/recent.htm

Jensen, L. (2006). At the razor's edge: Building hope for America's rural poor. Rural Realities, 1 (1). https://www.issuelab.org/resources/389/389.pdf

Jimerson, L. (2003). The competitive advantage: Teacher compensation in rural America. Policy Brief, Rural School and Community Trust, 2003 ED 474248. https://files.eric.ed.gov/fulltext/ED474248.pdf

Khattri, N., Riley, K. W., \& Kane, M. B. (1997). Students at risk in poor, rural areas: A review of the research. Journal of Research in Rural Education, 13(2), 79-100.

Kliebard, H. M. (2004). The struggle for the American curriculum. RoutledgeFarmer. https://doi.org/10.4324/9780203339985

Kozol, J. (2005). Shame of the nation: The restoration of apartheid schooling in America. Three Rivers Press.

Kraus, S. (n.d.). A call for New Ruralism. https://farmlandinfo.org/publications/a-call-for-new$\underline{\text { ruralism/ }}$ 
Lawrence, B. K. (1998). Working memory: The influence of culture on aspirations. ED 430765. https://files.eric.ed.gov/fulltext/ED430765.pdf

Lewis, H. (2007). Alternative values: The perennial debate about wealth, power, fame, praise, glory, and physical pleasure. Axios.

Lichter, D. T., \& Parisi, D. (2008). Concentrated rural poverty and the geography of exclusion. Rural Realities/Rural Sociology Society, University of New Hampshire. https://doi.org/10.34051/p/2020.55

Lockette, T. (2010, fall). Tapping the power of place. Teaching Tolerance (38), 16-19. https://www.learningforjustice.org/sites/default/files/general/Tapping_The_Power_38.pdf

Marx, K., \& Engels, F. (1998). The Communist manifesto. ElecBook. (Original work published in German, 1848; English translation published 1888).

Mattingly , M. J. \& Stransky, M. L. (2010). Young child poverty in 2009: Rural poverty rate jumps to nearly 29 percent in second year of recession. Carsey Institute Issue Brief 17. https://scholars.unh.edu/carsey/120/

Miller, B.A. (1993). Rural distress and survival: The school and the importance of "community." Journal of Research in Rural Education, 9(2), 84-103.

Morgan, J.Q., Lambe, W., \& Freyer, A. (2009) Homegrown responses to economic uncertainty in rural America. Rural Realties, 3(2) 1-15. https://www.ruralsociology.org/assets/docs/rural-realities/rural-realities-3-2.pdf

National Center for Education Statistics (2007, July 25). Status of Education in Rural America. NCES \# 2007040. http://arsl.pbworks.com/f/Status+of+Education+in+Rural+America+2007.pdf 
Noddings, N. (2002). Educating moral people: A caring alternative to character education. Teachers College Press.

O’Hare, W. P. \& Johnson, K. M. (2004). Child poverty in rural America. Population Reference Bureau Reports on America, 4 (1). https://scholars.unh.edu/soc_facpub/71

Oliver, J. P., \& Howley, C. (1992). Charting new maps: Multicultural education in rural schools. ERIC Clearinghouse on Rural Education and Small Schools. Digest EDO-RC92-1. https://files.eric.ed.gov/fulltext/ED348196.pdf

Rich, A. (1986). Invisibility in academe. In Blood, bread and poetry: Selected prose 19791985. W. W. Norton. (Essay written in 1984).

Rural School and Community Trust. (2010). A Rural Trust Guide to Title I Formulas. Rural Policy Matters. http://www.ruraledu.org/articles.php?id=2533

Slattery, P. (2006). Curriculum development in the postmodern era. Routledge.

Snyder, G. (2013). Reinhabitation. Manoa, 25(1), 44-48. https://doi.org/10.1353/man.2013.0010

Soffer, J. M. (2010). Ed Koch and the rebuilding of New York. Columbia University Press.

Strange, M. (2011). Finding fairness for rural students. Phi Delta Kappan, 92(6), 8-15. https://doi.org/10.1177/003172171109200603

Theobald, P. (1992). Rural philosophy for education: Wendell Berry's tradition. ERIC Clearinghouse on Rural Education and Small Schools. Digest EDO-RC 91-12. https://www.ericdigests.org/1992-3/rural.htm

Theobald, P. (1997). Teaching in the commons: Place, pride, and the renewal of community. Westview Press.

Theobald, P., \& Nachtigal, P. (1995). Culture, community, and the promise of rural education. Phi Delta Kappan, 77(2), 132-135. https://files.eric.ed.gov/fulltext/ED388464.pdf 
Tyack, D. (1974). The one best system: A history of American urban education. Harvard University Press. https://doi.org/10.2307/j.ctv136c61j

Veblen, T. (1979). Theory of the leisure class. Penguin. (Original work published 1899)

W. K. Kellogg Foundation. (2001). Perceptions of rural America. https://www.wkkf.org/ /media/0AE660039A644B778DF6745130DEE46E.ashx

Weber, M., Parsons, T., \& Tawney, R.H. (1958). The Protestant ethic and the spirit of capitalism. Scribner. (Origin work published 1905)

Wilbur, A. (2013). Growing a Radical Ruralism: Back-to-the-land as practice and ideal. Geography Compass, 7(2), 149-160. https://doi.org/10.1111/gec3.12023

Wood, R. E. (2008). Survival of rural America: Small victories and bitter harvests. University of Kansas Press.

\section{Author biography:}

V. Sue Atkinson retired in 2020 from a career teaching and supervising programs for infants through graduate students, working with both typically developing children and students with identified disabilities at the P-12 level. At SUNY Binghamton and Cortland, she trained teachers to work with these students with an emphasis on inclusive teaching practices. Sue continues this work on an occasional basis in retirement, and writes on topics related to education, policy, child development, and disability while enjoying her rural upstate New York home and continuing to advocate for the region's schools.

Sue received her Ed.D. in Educational Theory and Practice from the State University of New York at Binghamton in 2014, and her M.S.Ed. in early childhood special education from the 
same university. Her B.A. in Child Study is from Tufts University. Her most recent position was Visiting Assistant Professor at Binghamton University. 